ACTA VET. BRNO, 56, 1987: 251-260

\title{
ROENTGENOGRAPH OF EPIPHYSODIAPHYSEAL ZONE OF METAPODIUM IN CATTLE AS RELATED TO AGE
}

\author{
Č. ČERVENÝ, J. LUKAS and Hana STINGLOVA
}

Department of Anatomy, Histology and Embryology, University of Veterinary Science, 61242 Brno

Received January 20, 1986

A b s t r a c t

Červený Ø̌., J. Lukáš, Hana St inglová : Roentgenograph of Epiphysodiaphyseal Zone of Metapodium in Cattle as Related to Age. Acta vet. Brno, 56, 1987: 251-260.

A description is given of roentgenographs of the epiphysodiaphyseal growth zone and its residues in 72 Bohemian Pied cattle of both sexes from birth up to the age of 15 years. Typical age-dependent changes of this zone were detected and described, and the animals were allocated to 6 age groups according to radiographic findings. Our data thus enable to determine appro$x$ imately the age of cattle and can be of use in clinical practice, forensic medicine and also in archaeological osteology.

Age, morphological, changes, bones, cattle.

The epiphysodiaphyseal zones of long bones were studied by a number of authors from various aspects. The control of bone growth and factors acting on the ossification of epiphysodiaphyseal cartilage were described by $S i j b r a n d i j$ (1963) and He it (1964). We is s (1972) studied the changes in width of the epiphysodiaphyseal cartilage of long bones in pigs from birth till the cartilage disappearance. In cattle, data on the epiphysodiaphyseal growth zone are limited to the investigation of the period of its disappearance ( $K$ o l d a 1936; , B a r o $n$ e 1966). Both authors agree that the epiphysodiaphyseal cartilage in metapodium of cattle disappears at the age of two-to-two-and half years. The microstructure of the epiphysodiaphyseal growth cartilage in metatarsus of cattle in ontogenesis was described by $L$ a silla (1928), while in man and dog by $\mathrm{H}$ a ines (1975). In the epiphysodiaphyseal growth zone $\mathrm{H}$ a in es (1975) differentiated the epiphyseal and diaphyseal osseous plate in addition to the epiphysodiaphyseal growth cartilage. In radiographs of epiphysodiaphyseal zone B láh a (1963) designated these osseous plates as "epiphyseal and metaphyseal zones of temperary calcification".

B ine v (1970) carried out radiographic studies of skeleton of limbs in cattle. He described the RTG-picture of epiphyses 
of bones of limbs in newborn and in one-month old calves. The RTG-picture of carpal bones was studied by $F u n k$ (1966) on the basis of comparison with rich osteological material. The roentgenograph of growth changes in distal digit phalanges in cattle was described by 5 imon (1963). The epiphysodiaphyseal growth zones are mostly only mentioned in the radiology of domestic animals on roentgenographs ( C a r 1 s o n 1967; M o r ga n 1972). Cerveny (1980) studied the macrostructure and RTG-picture of epiphysodiaphyseal growth zones in metapodium and acropodium of cattle in postnatal ontogenesis. He described variously formed radiolucencies remaining after epiphysodiaphyseal cartilages and shadows of osseous plates and/or epiphysodiaphyseal junctions as dependent on age. The author found that these epiphysodiaphyseal junctions gradually disappear with increasing age of cattle due to internal reconstruction of bone.

Described in this paper in more detail is the radiograph of epiphysodiaphyseal growth zones and their changes in postnatal ontogenesis in cattle with the objective to specify the characteristic features of their RTG-picture typical of certain age periods.

\section{Materials and Methods}

A total of 288 radiographs of metapodium of 72 individuals of Bohemian Pied cattle from birth to 15 years of age of both sexes were studied ( 16 males and 56 females). Pictures were taken with the aid of $X$-ray apparatus "Durolux" and portable $X$-ray apparatus "Chirax" in dorsopalmar (-plantar) projection. Radiographs were evaluated on roentgenoscope $L-110$ with perfectly dispersed homogeneous illumination. Evaluated was the radiolucency of epiphysodiaphyseal growth cartilage, beginnings of its extinction, then the range of shadows of the epiphyseal and diaphyseal osseous plate and outlines of epiphysodiaphyseal junction and its extinction. We also evaluated the shape of outer edge of bones at the level of epiphysodiaphyseal growth zone.

Res u 1 t s

Based on the changes in radiographs of epiphysodiaphyseal growth cartilage, epiphyseal and diaphyseal osseous plate and, later on, of epiphysodiaphyseal junction we suggested classification of the studied series of cattle in the following six age groups.

Age group I : Comprised the animals from birth to 2 years of age. (Fig. 1, 2). Typical trait was the epiphysis separated from the diaphysis in the whole range of epiphysodiaphyseal junction of metapodium. In newborn and young individuals the radiolucency remaining after the epiphysodiaphyseal cartilage was wide and inexpressively undulated (Fig. 1). With advancing age this radiolucency became thinner and distinctly undulated. 
Another trait is a distinct prominence of outer circumference of the epiphysodiaphyseal growth zone over the bone.surface (Fig. 1, 7). The substantia spongiosa is homogeneously outlined. The osseous plates associated with the epiphysodiaphyseal cartilage (Fig. 2) - wider diaphyseal and narrower epiphyseal ones, are depicted by darker shadow. In newborns these are inexpressive and with advancing, age form darker shadows on radiograms in this age group.

Age group I I : Comprised the animals within the age range of completed 2nd to completed 3rd year (Fig. 3). The epiphysodiaphyseal growth cartilage of the metapodium growth zone begins to disappear and synostosis of the diaphysis with the epiphysis series in, namely, first in axial direction where the epiphysodiaphyseal junction began to form. At the periphery in abaxial circumference of metapodia, the epiphysodiaphyseal growth cartilage is maintained for the longest time (Fig 3,1 ).

The spongiosis of distal end of diaphyses and epiphyses of the metapodia is homogeneously outlined. The outer circumferential edges of epiphysodiaphyseal growth zone project still more expressively over the bone surface (Fig. 3, 5). The epiphyseal and the diaphyseal bony plate (Fig. 3, 2, 3) are conspicuous in the form of deep shadow at the circumference of growth zone on the radiograph. In the centre of metapodium both the bony plates fuse into the epiphysodiaphyseal junction (Fig. 3, 4).

A ge group I I I:: Consisted of animals from completed 3rd to completed 4 th year (Fig. 4). The epiphysodiaphyseal growth certilage of the metapodium was substituted in the whole range by the osseous epiphysodiaphyseal junction. It is perceptible on the radiograph as a sharp line of shadow, relatively wide, particularly at the abaxial circumference of the epiphysodiaphyseal junction of metapodium (Fig. 4, 3). The substantia spongiosa of the metapodium is homogeneously drawn and the edges of junction project over the outer (abaxial) edges of the metapodium inconspicuously (FIg. 4, 4).

A ge group I : Consisted of animals aged from completed 4 th to completed 8 th year (Fig. 5). The epiphysodiaphyseal junction of the metapodium is drawn in the whole range as a thin sharp line of shadow (Fig. 5, 1). Here the osseous plates disappeared entirely, the substantia spongiosa in the vicinity of the epiphysodiaphyseal junction is regularly-dramn. The peripheral edges of the junction project only inconspicuousliy over the outer edges of the metapodium.

A ge group $V$ : Comprised the animals aged from completed 8 th to completed 14 th year. In the region of epiphysodiaphyseal junction regressive changes appear manifesting themeselves as indication of resorption of osseous trabecula forming the epiphysodiaphyseal junction. This resorption proceeds again from the centre of the bone to the periphery (Fig, 6, 1). In the radiograph the junction appears as not sharp line of shadow, while being relatively clearly outlined in younger animals of this age group. At older age within this group the line of shadow of the 


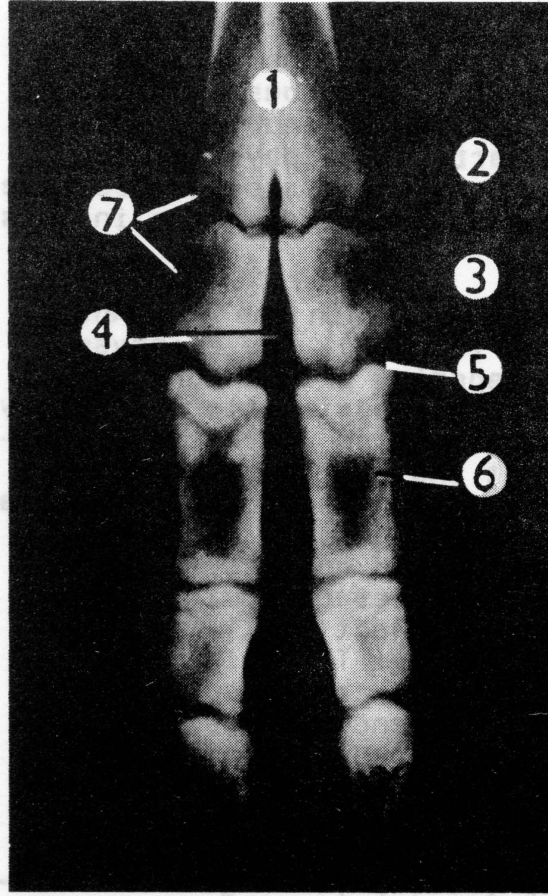

Fig. 1. Radiograph of the distal end of autopodium of the left thoracal limb of a newborn calf in palmadorsal projection. 1 - os metacarpale II et IV (corpus), 2.- radiolucency remaining after high epiphysodiaphyseal growth cartilage, 3 - os metacarpale III (epiphysis), 4 - incisura intertrochlearis, 5 - radiolucency of articular space of articulatio metacarpophalangea, 6 - phalanx proximalis digiti III, 7 - edges of epiphysodiaphyseal growth zone projecting over the bone surface.

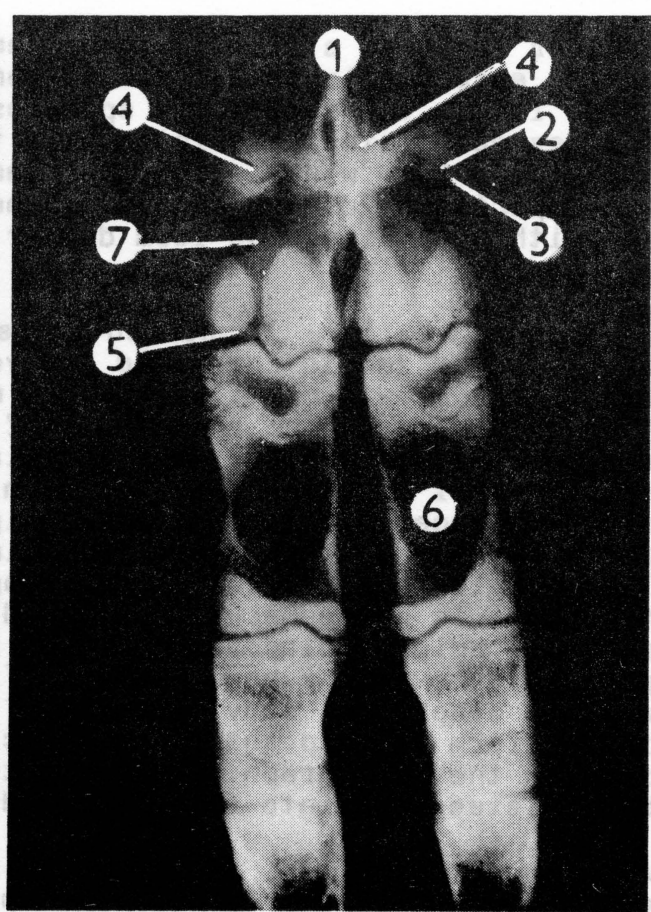

Fig. 2. Radiograph of the distal end of autopodium of the right pelvic limb. of cattle in plantadorsal projection (age: 8 months - age group I). 1 - os metatarsale III et IV (corpus), 2 - radiolucency remaining after conspicuously. undulated epiphysodiaphyseal cartilage is bounded with narrow shadow of epiphyseal (3) and wide shadow of diaphyseal bony plate (4), 5 - radiolucency of articular space of articulatio metatarsophalangea, 6 - phalanx proximalis digiti IV, 7 - os metacarpale III (epiphysis).

junction is, in the central section, not sharp up to imperceptible. The outer circumference of junction does not project over the outer circumference of the metapodium distal end. The substantia spongiosa does not manifest regular outlines, its structure is coarser with alternating radiolucent and radiopaque spots (Fig. 6,2 ). 


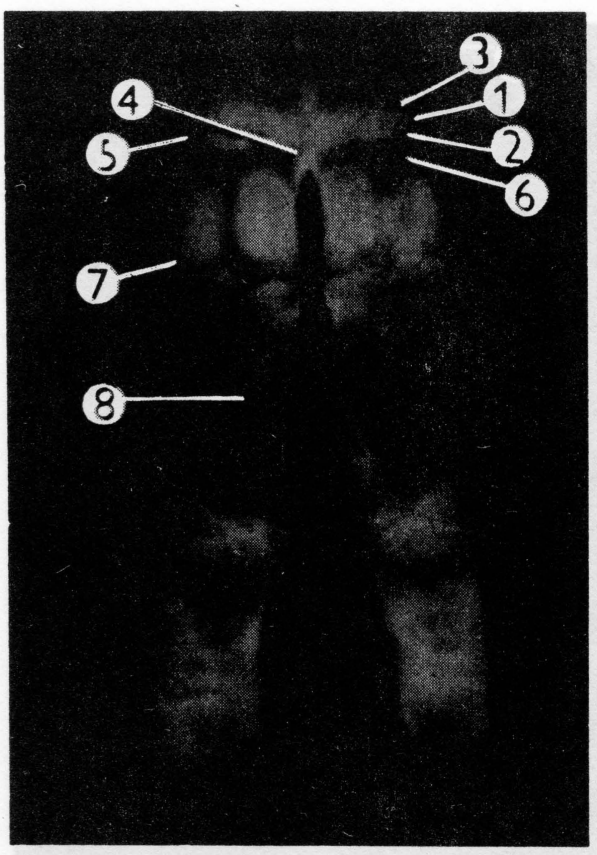

Fig. 3. Radiograph of the distal end of autopodium in palmadorsal projection (age group II). 1 - radiolucency remaining after epiphysodiaphyseal growth cartilage on the circumference of epiphysodiaphyseal growth zone, 2 - epiphyseal and diaphyseal (3) bony plates which fuse in the central part of metacarpal bones after disappearance of epiphysodiaphyseal growth cartilage and form the epiphysodiaphyseal junction (4), 5 - edges of epiphysodiaphyseal growth zone project over the outer contour of bones, 6 - epiphysis ossis metacarpalis III, 7 - radiolucency of articular space of articulatio metacarpophalangea, 8 - phalanx proximalis digiti IV.

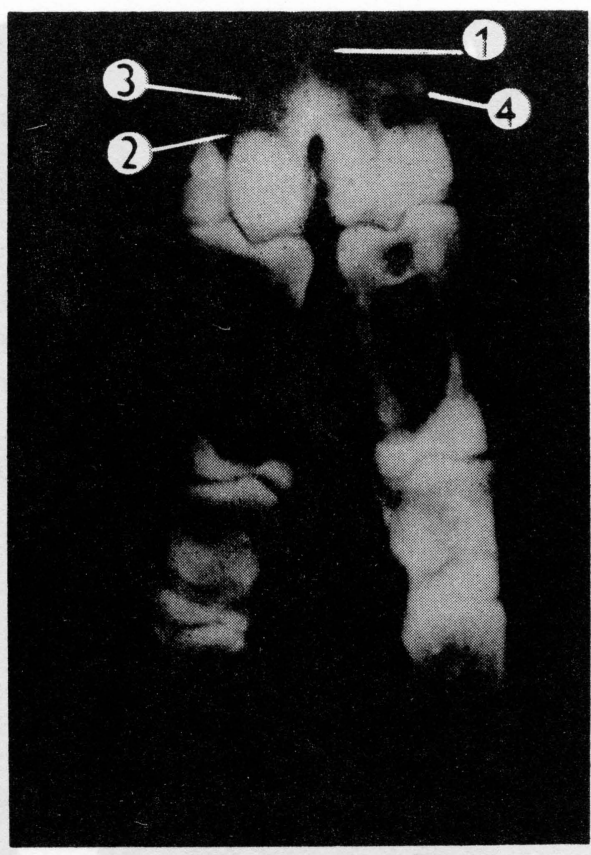

Fig. 4. Radiograph of the distal end of autopodium of the left thoracal 1 imb of 4 -year old cow in palmadorsal projection (age group III). 1 - os metacarpale III et IV (corpus), 2 - os metacarpale III (epiphysis), 3 - clearly drawn shadow of epiphysodiaphyseal junction which is still wide, 4 - outer edges of epiphysodiaphyseal junction prominent over the bone surface inconspicuously only. 


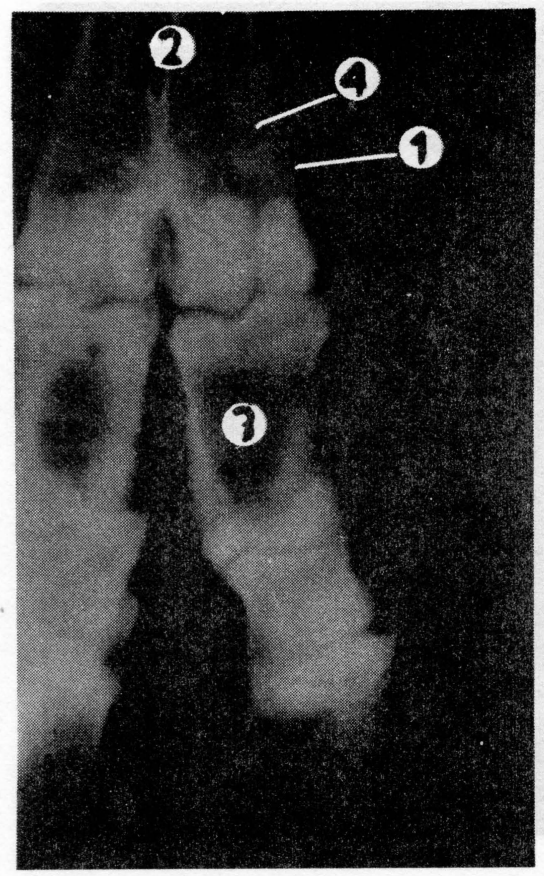

Fig. 5. Radiograph of the distal part of autopodium of the right thoracal limb of 6-year old cow in dorsopalmar projection. 1 - clearly drawn shadow of narrow epiphysodiaphyseal junction, 2 - os metacarpale III et IV, 3 - phalanx proximalis of the fourth digit, 4 - substantia spongiosa.

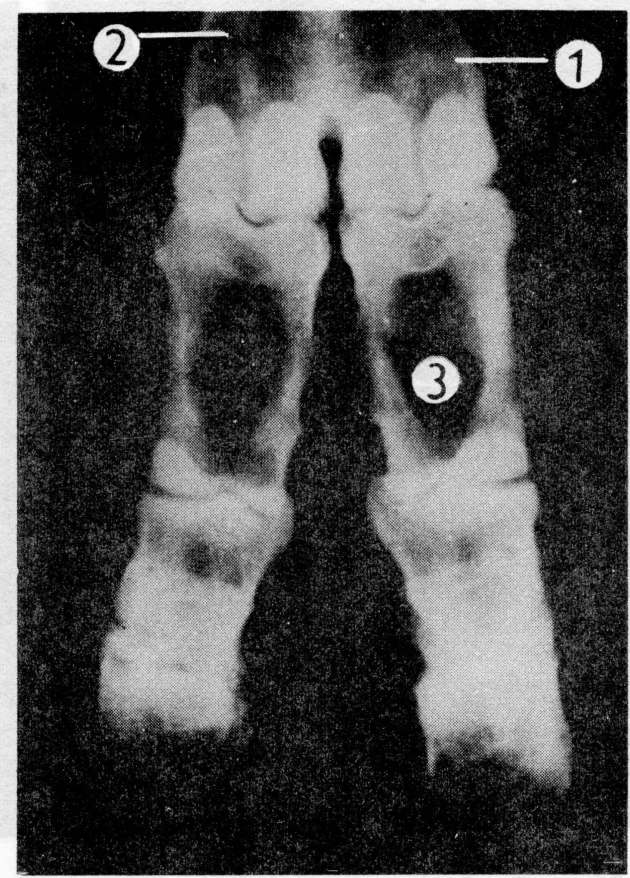

Fig. 6. Radiograph of the distal part of autopodium of the right thoracal limb of 10-year old cow in dorsopalmar projection. 1 - narrow epiphysodiaphyseal junction with signs of resorption, 2 - substantia spongiosa of the metapodium distal end, 3 - phalanx proximalis of the third digit.

Age group V I: This age group comprised animals older than 14 years. The shadow of osseous trabecula of the epiphysodiaphyseal junction is in indication only in the radiograph being entirely missing locally. Conspicuous are residua while in the peripheral circumference of the metapodium. Due to the reconstruction of bones almost complete resorption of trabeculae of the epiphysodiaphyseal junction occurred. The substantia spongiosa is non homogeneous, the trabeculae are thinner, coarser with conspicuous cleared up spots locally. The outer edges of bone at the level of junction do not project over the outer circumference of bone, the distal part of the metapodium has a characteristic conical shape. 


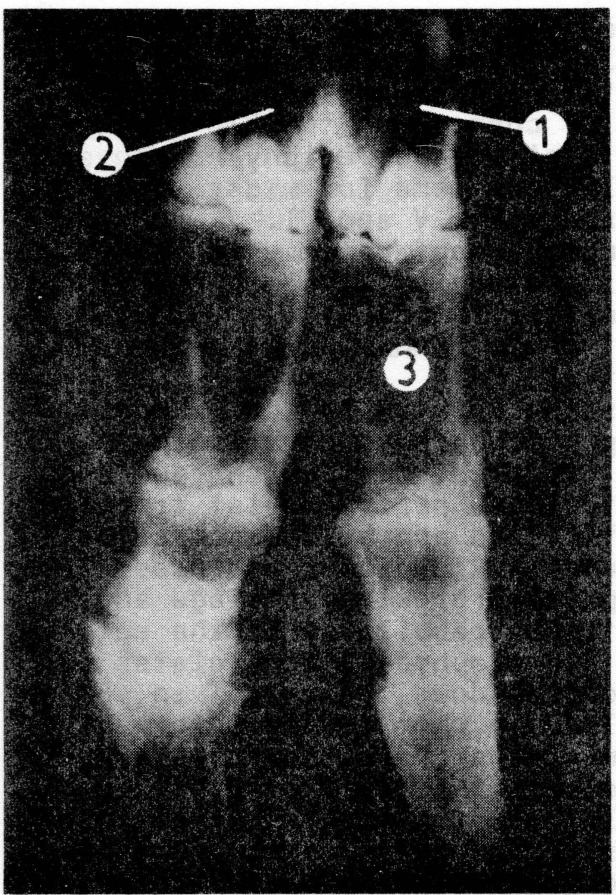

Fig. 7. Radiograph of the autopodium distal end of the left pelvic limb of 15-years old cow in dorsoplantar projection. 1 - line of epiphýsodiaphyseal junction is indicated only locally, 2 - extensive spots of radiolucency in substantia spongiosa, 3 - phalanx proximalis of the fourth digit.

The epiphysodiaphyseal growth zone of bone is subjected, even in the postnatal development, to constant morphological changes that are a result of above all the growth activity of epiphysodiaphyseal growth cartilage and, later on, of its destruction and, also, due to the functional rebuilding of the bone structure. After disappearing the epiphysodiaphyseal growth cartilage, in the place of former epiphysodiaphyseal zone, the epiphysodiaphyseal junction originates which changes its radiographic pattern in the course of individual's ageing.

The radiographic veterinary monographies (C a r 1 s o n 1967 , Morgan 1972) do not pay adequate attention to the epiphysodiaphyseal zones of bones, though these are, from the viewpoint of biological dynamics and metabolism of bones, very important.

The detailed description of RTG-picture of the epiphysodiaphyseal zones and description of its changes as dependent on age is presented by $\check{C}$ e r ve ný (1980). The author, however, does not present the enumeration of changes in the radiographs typical for certain age ranges of studies animals. Based on deeper study of the set of RTG-pictures of the autopodium of cattle we were able to define the signs for the proposed age groups of cattle. In the age group I (from birth to 2 years), rather conspicuous changes are due to very active growth of bo- 
ne and its reconstruction in the course of development. Originating and, later on, reconstructing after the disappearance of the epiphysodiaphyseal growth cartilage is the osseous epiphysodiaphyseal junction. The dynamics of changes on the RTG-picture is decelerated. That is why the RTG-picture of epiphysodiaphyseal junction and its vicinity is usually the same for wider range of ages as seen in findings of age groups IV, $V$ and $V I$.

Our findings in radiographs cannot be confronted with literatury data, since the radiologic literature relating to the RTG-picture of skeleton of bones in cattle (F u nk 1966, 5 i m o n 1966, Binev 1970 and $B$ u $t$ et al. 1968) does not describe epiphysodiaphyseal zones in detail.

From the conclusions of $S i j b r a n d i j(1963)$ and $H e ~ t$ (1964) it follows that the closing procedure of cartilaginous epiphysodiaphyseal growth zone is effected, besides the age and sex of individual, also by periosteal and perichondrial traction, further by muscular traction, static load and by the articular capsule. Morphological changes found in RTG-pictures proceed after the involution of the epiphysodiaphyseal growth cartilage and originate because of the osseous tissue rebuilding in the epiphysodiaphyseal zone. The epiphyseal and diaphyseal bony plates of the growth zone are depicted as deep shadows, above all in young animals (in age group I, II and III), in whom the more intensive reconstruction of newly formed bone takes place. Corresponding with this are more intensive shadows in this part of growth zone brought about by increased accumulation of mineral salts in the epiphysodiaphyseal region. Osseous trabeculae of the spongiosis, in animals classed into higher age groups (group $V$ and VI) grow coarser and spaces between them expand. In extremely old individuals, this may leadito "senile" osteoporosis which then appears in the radiographs as irregular foci of radiolucency (C a r ls on 1967). Rentgenový obraz epifysodiafysárni zóny metapodia skotu
ve vztahu k véku

Na základě studia rentgenogramú metapodil 72 kusú skotu českého strakatého plemene samçho i samičlho pohlavi jsme popsali rentgenový obraz epifysodiafysárni rústové zóny a jejich reziduí $v$ obdobl od narozeni do 15 let věku. Vymezili jsme typické rentgenem zjistitelné změny $v$ závislosti na věku a dle těchto změn jsme rozdělili sledovanou kolekci zvirat do 6 věkových skupin. Na základě zjistěných údajù lze přibližriè stanovit věk skotu. Výsledky lze aplikovat $v$ klinické praxi, soudnich expertizách a navrženou metodu uplatnit $v$ archeologické osteologii. 
Рентгеновская хартина эпифизо-диафизарной зоны метаподия хрупного рогатого скота по отнотению $x$ возрасту

Изучая рентгенограммы метаподи 72 голов хрупного рогатого скота чешской пестрои обоих полов, описали рентгеновскую картину эпифизо-диафизарной зоны роста и их остатков начиная с рождения и кончая 15-летним возрастом. Нами были определены харахтерные, рентенограммой выявляемые изменения в зависимости от возраста и, основываясь на упомянутых изменениях, разделили исследуемых цживотных на 6 возрастных групп. На основе установленных данных можно приблизительно определить возраст хрупного рогатого скота. Результаты можно применить в клинической практике, судебных ехспертизав и представлениы метод-в археологичецкой остеологии.

References

BARONE, R.: Anatomie comparée des mammifères domestiques. S. A. Tisiér; Lyon 1966, pp. 811 .

BINEV, K.: Normalna rentgenova kartina na kostnostavnija aparat na krajncite pri novorodeni i ednomesecni telata ot porodata blgarsko kafjabo govedo. Nauč. trudy Vys. vet. med. inst. im. Pavlova, 22, 1970: 357-367.

BLÁHA, R.: Rentgenologie kosti a kloubú. SZN Praha, 1963, pp. .853.

BURT, J. K. - MYERS, V. S. - HILLMAN, D. J. - GETTY, R.: The radiographic locations of epiphyseal lines in bovine limbs. Am. J. Vet. Med. Ass., 152, 1968: 168-174.

CARLSON, W. D.: Veterinary radiology. Lea and Febiger, Philadelphia, 1967 , pp. 666.

CERVENY, ¿.: Epiphysodiaphyseal growth zones in metapodium and acropodium of cattle in postnatal ontogenesis. Acta.vet. Brno, 49, 1980: $11-30$.

FUNK, K.: Röntgenanatomische Untersuchungen am Karpalskelett des Rindes. Thesis, Tierärztliche Hochschule Hannover, 1966, pp. 41 .

HAINES, W. R.: The histology of epiphyseal union in mammals. J. Anat., 120, 1975: 1-25.

HEŘT, J.: Regulace rústu dlouhých kostí do délky. Acta chir. orthop. et traumatol. Plzeñ, 31, 1964: 222-226.

KOLDA, J.: Srovnávaci anatomie zviłat domácich se zretelem $k$ anatomii clověka. Novina, Brno, 1936, pp. 914.

LASILLA, V.: Beiträge zur Kenntniss der Entwicklung und Verknöcherung des sogenanten Fugenknörpels. Annales Acad. Sci. Fennicae, Ser. A, 1928: 1-220.

MORGAN, J.P.: Radiology in Veterinary orthopedics. Lea and Febiger, Philadelphia, 1972 , Pp. 406.

SIJBRANDIJ, S.: Inhibition of tibial growth by means of compression of its proximal epiphyseal disc in the rabbit. Acta anatomica, 55, 1963, 278-285.

SIMON, G.: Untersuchungen über altersbedingte Veränderungen des Klauenbeine des Rindes. Thesis, Tierärztliche Hochschule Zürich, 1963, pp. 26.

SMITH, R. N. - ALLOCK, J.: Epiphyseal fusion in the Greyhound. Vet. Rec., 72, 1960: 75-79. 
WEISS, R.: Röntgenologische Feststellung des Epi- und Apophysenfugenschlusses beim Schwein. Thesis, Tieräztliche Hochschule Hannover, 1972, Pp. 67. 